\title{
Effect of Organizational Citizenship Behavior and Discipline on the Company Performance through Motivation as Variable Mediation in PT. Henkel Indonesia
}

Yudha Yan Kusuma*, Harry Indratjahyo, Bongsu Saragih

Universitas Krisnadwipayana Campus Unkris Jatiwaringin PO BOX 7774/Jat CM Jakarta 13077, Indonesia

\begin{tabular}{|c|c|}
\hline $\begin{array}{c}\text { Article History } \\
\text { Received: } 05.10 .2020 \\
\text { Accepted: } 21.10 .2020 \\
\text { Published: } 26.10 .2020 \\
\text { Journal homepage: } \\
\text { https://www.easpublisher.com/easjebm }\end{array}$ & $\begin{array}{l}\text { Abstract: This study aims to examine organizational citizenship behavior and discipline } \\
\text { on company performance through motivation. The research was conducted at PT Henkel } \\
\text { Indonesia with a sample size of } 222 \text { respondents. The sampling technique is saturated } \\
\text { sample and data analysis uses path analysis. The results showed that organizational } \\
\text { citizenship behavior variables partially influence company performance. The discipline } \\
\text { variable partially affects company performance. Motivation variables partially affect } \\
\text { company performance. Organizational citizenship behavior variables partially influence } \\
\text { motivation. The discipline variable partially affects motivation. The effect of } \\
\text { organizational citizenship behavior on company performance is } 0.600 \text {. The influence of } \\
\text { organizational citizenship behavior on performance through motivation is } 0.712 \mathrm{x} 0.878 \\
=0.625 \text {. The direct effect of organizational citizenship behavior on company } \\
\text { performance is } 0.657 \text {. While the influence of work organizational citizenship behavior on } \\
\text { company performance through motivation is } 0.772 \mathrm{x} 0.878=0.678 \text {. In this case, the } \\
\text { work motivation variable is intervening. } \\
\text { Keywords: Organizational citizenship behavior, discipline, motivation, company } \\
\text { performance. }\end{array}$ \\
\hline
\end{tabular}

Copyright ( 2020 The Author(s): This is an open-access article distributed under the terms of the Creative Commons Attribution 4.0 International License (CC BY-NC 4.0) which permits unrestricted use, distribution, and reproduction in any medium for non-commercial use provided the original author and source are credited.

\section{INTRODUCTION}

Company performance is something that is produced by an organization that includes outcomes, namely financial performance such as profit as measured by return on assets, return on investment, and so on, market performance such as an expansion of market share, and sales. Besides, the return from the shareowner is the return of the shareowner and the economic increase of the shareowner. In some areas, company performance can also be measured from other things such as strategic planning, operations, finance, legal and organizational development. Developing an institution or organization is a must to survive in the competitive climate of the world.

The goals of productivity are related to the development of the organization [1]. Small organizations have the desire to keep growing and becoming big. The developing organization is to come back to the development itself. Measuring company performance according to the PBM GIS concept (the performance-based management special interest group is by monitoring and reporting the program it is running, and paying attention to the objectives achieved. The performance is measured based on the process of activities in the program being carried out, the products produced, and services Noe, et al. [2] explained that to obtain maximum company performance, a company needs employees who have maximum individual performance as well. HR has a dominant role in processing resources and materials so that they become products through its policies. To improve performance, it is necessary to get sufficient attention so that HR can work efficiently and produce a performance that can contribute to organizational productivity.

Firm performance is influenced by organizational citizenship behavior, discipline, and motivation. Organizational Citizenship Behavior (OCB) is behavior that is not part of the duties that have been formally required for an employee but as a whole encourages the effective functioning of the organization [3]. In terms of organizational effectiveness, individuals in a team need to have supportive behavior. This behavior is not only in-role behavior but is expected to generate extra-role behavior from the individual so that the teamwork can be more solid and can work optimally for the organization [4]. Organizational Behavior (OB) or we also call organizational behavior is a science that studies human behavior in an organization and how that behavior impacts the organization. One of the behaviors that give this impact is Organizational Citizenship Behavior (OCB). 
Another factor that affects company performance is work discipline. According to Dessler [5] discipline is a procedure that corrects or punishes someone dangerous for violating a rule or procedure. Arikunto [6] discipline is a person's obedience in following rules or regulations because it is driven by the awareness that exists in his conscience without any coercion from outside parties. Discipline is a sense of obedience and obedience to the values that are believed and it is their responsibility. In other words, discipline is obeying the rules or subject to supervision and control. Meanwhile, discipline is an effort that is carried out to instill value or force so that the subject obeys a rule. Discipline is an attitude that is always right on promises so that other people believe because someone's capital in entrepreneurship is to get the trust of others. Another factor that affects company performance is motivation. Motivation is an impulse that causes a person to do an action to achieve a certain goal. Motivation comes from the word motive which means "impulse" or stimulation or "driving force" that is within a person. According to Weiner [7], motivation is defined as an internal condition that arouses us to act, encourages us to achieve certain goals, and keeps us interested in certain activities. According to Uno [8], motivation can be interpreted as internal and external encouragement in a person as indicated by their existence; passions and interests; urges and needs; hopes and ideals; appreciation, and respect. Motivation is something that makes someone act [9] states that motivation is the impact of a person's interaction with the situation he is facing [10].

Motivation becomes a force, energy or power, or a complex situation and readiness in the individual to move towards a specific goal, whether consciously or not [11]. A person's motivation can be generated and grow through himself-intrinsic and extrinsicenvironment [12]. Intrinsic motivation means the desire of oneself to act without external stimulation [12]. Intrinsic motivation will be more profitable and provide consistency in learning. Extrinsic motivation is defined as motivation that comes from outside the individual and cannot be controlled by the individual [9]. Elliott et al. [12], exemplified the values, gifts, and rewards that are used to stimulate a person's motivation.

\section{LITERATURE REVIEW Organizational Citizenship Behaviour}

Organizational Citizenship Behavior (OCB) is behavior that is not a part of the duties that have been formally required for an employee but as a whole encourages the effective functioning of the organization [3]. In terms of organizational effectiveness, individuals in a team need to have supportive behavior. This behavior is not only behavior that is following the role but it is expected that the extra-role behavior of the individual is so that the teamwork can be more solid and can work optimally for the organization [4]. Apart from the above definitions, Podsakoff [13] also provides five dimensions of Organizational.

\section{Citizenship Behavior (OCB):}

- Altruism: behavior that influences helping colleagues in the cubicle.

- Conscientiousness: behavior that is part of employees who carry out tasks that exceed the minimum requirements.

- Sportsmanship: the feeling of employees to refrain from complaints about things that do not enter.

- Courtesy: behavior that is part of the person who replaces others in the organization about changes that affect their work.

- Civic virtue: behavior belonging to the company which indicates that they are deep in calculating.

Individual behavior that is free and spontaneous resulting from the character of a person or character of work or organization also comes from relationships with superiors. This behavior is carried out in the organization or co-workers, which increases organizational improvement through direct influence from work or indirect social influence that increases interpersonal relationships. Organizational citizenship behavior is not described as informal employment, nor is it contractually rewarded.

\section{Discipline}

According to Dessler [5], the definition of discipline is a procedure that corrects or punishes someone dangerous for violating a rule or procedure. According to James Drever, the definition of discipline is a person's ability to control behavior that comes from within a person according to things that have been regulated from outside or existing norms. In other words, discipline from a psychological perspective is the behavior of a person who appears and can conform to predetermined rules. According to Arikunto [6], the definition of discipline is a person's obedience in following rules or regulations because it is driven by the awareness that is in his conscience without any coercion from outside parties. According to Siswanto [14], the definition of discipline is an attitude of respecting, appreciating, obeying and obeying the applicable regulations, both written and unwritten and being able to carry them out and not avoiding receiving sanctions if he violates his duties and authority given to him.

\section{Motivation}

Motivation is an impulse that causes someone to do an action to achieve a certain goal. Motivation comes from the word motive which means "impulse" or stimulation or "driving force" that is within a person. According to Weiner [7] quoted by Elliot et al. [12], motivation is defined as an internal condition that arouses us to act, encourages us to achieve certain goals, and keeps us interested in certain activities. 
According to Uno [8], motivation can be interpreted as internal and external encouragement within a person as indicated by their existence; passions and interests; urges and needs; hopes and ideals; appreciation and respect. Motivation is something that makes someone act [9] states that motivation is the impact of a person's interactions with the situation he is facing [10].

Motivation becomes a force, energy or power, or a complex situation and readiness in the individual to move towards a certain goal, whether consciously or not [11].

A person's motivation can be generated and grow through himself-intrinsic and extrinsicenvironment [9]. Intrinsic motivation means the desire of oneself to act without external stimulation [12]. Intrinsic motivation will be more profitable and provide consistency in learning. Extrinsic motivation is defined as motivation that comes from outside the individual and cannot be controlled by the individual [9]. Elliott et al. [12], exemplified the values, gifts, and / or rewards that are used to stimulate a person's motivation.

For example, in learning activities, motivation is the driving force that ensures the continuity of learning activities and provides direction for learning activities so that the desired goals can be met. Thus motivation is very influential on one's learning outcomes. If someone does not have the motivation to learn, that person will not achieve optimal learning outcomes. To be able to learn well, it requires good process and motivation, providing motivation to learners, meaning moving someone so that he wants or wants to do something. Motivation can be viewed as a function, meaning that motivation functions as a driving force from within an individual to carry out certain activities in achieving goals.

Motivation is seen in terms of process, meaning that motivation can be stimulated by external factors, to generate motivation in students who go through the stimulation process of learning so that they can achieve the desired goals. Motivation is viewed in terms of goals, meaning that motivation is the stimulus target to be achieved. If a person has the desire to learn something, then he will be motivated to achieve it.

\section{Company Performance}

The definition of company performance refers to the ability of employees to carry out all the tasks that are their responsibility. These tasks are usually based on indicators of success that have been implemented. As a result, it will be known that an employee belongs to a certain level of work. The level can be various terms. Performance can be categorized as over target, on target or under target. Departing from the things referred to as a whole for the work of an employee. The definition of organizational performance is a description of the level of achievement of the implementation of an activity program or policy in realizing the goals, objectives, vision and mission of the organization as outlined in the strategic planning of an organization [15]. Mangkuprawira [16] says that performance is a matter, or the overall success rate of a person during a certain period in carrying out a task compared to various possibilities, such as work standards, targets, or targets or criteria that have been determined in advance and have been agreed together.

According to Wibowo [17], performance is a management style in managing performance-oriented resources that carries out an open and sustainable communication process by creating a shared vision and a strategic and integrated approach as a driving force to achieve organizational goals. According to Rivai and Sagala [18] suggest that: "Performance is a function of motivation and ability to complete a task or someone's job should have a certain degree of willingness and level of ability.

\section{RESEARCH METHODS \\ Time and Location of Research}

The research will be conducted in OctoberDecember 2019 by taking the location at PT. Henkel Indonesia.

\section{Research Design}

This study uses an explanatory analysis approach. This means that each variable presented in the hypothesis will be observed through testing the causal relationship of the independent variable to the dependent variable.

\section{Population and Sample}

The population in this research are employees who work at the PT. Henkel Indonesia. While the sample used includes 222 employees who work in company offices. This sampling uses the saturated sample method because it uses all employees at the company office.

\section{Data Analysis Technique}

The stages of data processing in this research are classical assumption test with regression such as linearity test, heteroscedasticity test, normality test, multicollinearity and autocorrelation test as well as search for descriptive statistics, namely the mean value, median mode, standard deviation and range.

\section{RESEARCH RESULT}

Analysis of the Partial Influence of Organizational Citizenship Behavior on Company Performance

The result of the analysis of the effect of organizational citizenship behavior on company performance is partially known that the coefficient of organizational citizenship behavior is 0.600 . The $t$ value is 11,133 . The significance value is 0.00 . This significant value is smaller than 0.05 . This means that 
the organizational citizenship behavior variable partially affects company performance. The magnitude of the influence of organizational citizenship behavior on company performance can be seen that the value of $r$ squared is 0.360 . This means that the influence of the organizational citizenship behavior variable on performance is $36.0 \%$ and the rest is influenced by other variables that are not included in the equation model.

\section{Analysis of the Partial Effect of Work Discipline on Company Performance}

The results of the analysis of the effect of discipline on company performance partially show that the coefficient of discipline is 0.658 . The $t$ value is 12,975 . The significance value is 0.00 . This significant value is smaller than 0.05 . This means that the discipline variable partially affects company performance. The magnitude of the influence of discipline on company performance can be seen that the value of $r$ squared is 0.433 . This means that the influence of the discipline variable on company performance is $43.3 \%$ and the rest is influenced by other variables that are not included in the equation model.

\section{Partial Analysis of the Influence of Motivation on Company Performance}

The results of the analysis of the effect of work motivation on company performance partially show that the motivation coefficient is 0.878 . The $\mathrm{t}$ value is 27.146. The significance value is 0.00 . This significant value is smaller than 0.05 . This means that the motivation variable partially affects company performance. The magnitude of the influence of motivation on company performance is known to be the value of $r$ squared of 0.770 . This means that the influence of the motivation variable on company performance is $77.0 \%$ and the rest is influenced by other variables that are not included in the equation model.

\section{Analysis of the Partial Influence of Organizational Citizenship Behavior on Motivation}

The results of the analysis of the effect of organizational citizenship behavior on motivation partially show that the coefficient of organizational citizenship behavior is 0.712 . The $t$ value is 15.021 . The significance value is 0.00 . This significant value is smaller than 0.05. This means that the variable of organizational citizenship behavior partially affects motivation. The magnitude of the influence of organizational citizenship behavior on motivation is known to be the value of $r$ squared of 0.506 . This means that the influence of the motivation variable on company performance is $50.6 \%$ and the rest is influenced by other variables that are not included in the equation model.

\section{Partial Analysis of the Effect of Discipline on Motivation}

The results of the analysis of the effect of discipline on motivation partially show that the coefficient of discipline is 0.772 . The t value is 18.039 . The significance value is 0.00 . This significant value is smaller than 0.05 . This means that the discipline variable partially affects motivation. The magnitude of the influence of discipline on motivation is known to have the $r$ squared value of 0.597 . This means that the influence of the discipline variable on motivation is $59.7 \%$ and the rest is influenced by other variables that are not included in the equation model.

\section{Analysis of the Effect of Organizational Citizenship Behavior on Company Performance through Motivation Variables}

Based on the partial path analysis above, it can be described as follows. The analysis is an analysis on a path with a substructure image as follows.

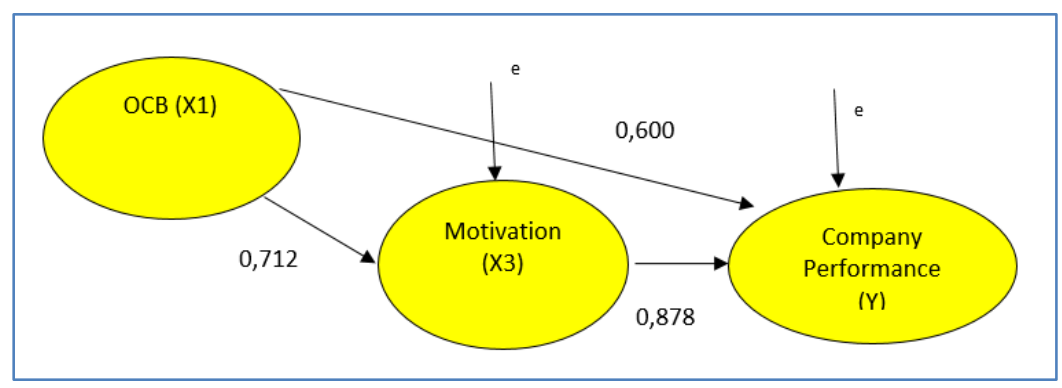

Fig-1: Path analysis of the influence of X1 on Y through X3

Based on the figure above, it can be seen that the influence of organizational citizenship behavior on company performance is 0.600 . The influence of organizational citizenship behavior on performance through motivation is $0.712 \times 0.878=0.625$. In this case, the indirect effect is greater than the direct effect, so it can be said that the work motivation variable is intervening.

\section{Analysis of the Influence of Work Organizational Citizenship Behavior on Company Performance through Motivation Variables}

Based on the partial path analysis above, it can be described as follows. The analysis is an analysis on a path with a substructure image as follows. 


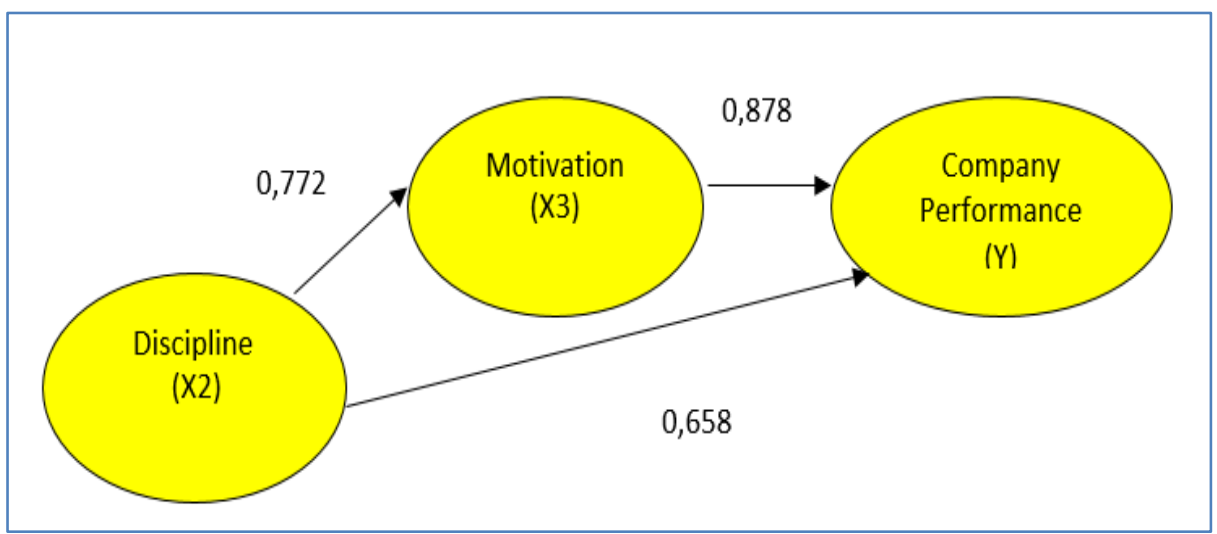

Fig-2: Path analysis of the influence of X2 on Y through X3

Based on the picture above, it can be seen that the direct effect of organizational citizenship behavior on company performance is 0.657 . While the influence of work organizational citizenship behavior on company performance through motivation is $0.772 \mathrm{x}$ $0.878=0.678$. In this case, the indirect effect is greater than the direct effect, so it can be said that the work motivation variable is intervening.

\section{CONCLUSIONS AND RECOMMENDATIONS}

\section{Conclusions}

Organizational citizenship behavior variables partially influence company performance. The $t$ value is 11,133 . The significance value is 0.00 . This significant value is smaller than 0.05 . The value of $r$ squared is 0.360. This means that the influence of the organizational citizenship behavior variable on performance is $36.0 \%$ and the rest is influenced by other variables that are not included in the equation model.

The discipline variable partially affects company performance. The $\mathrm{t}$ value is 12,975 . The significance value is 0.00 . This significant value is smaller than 0.05 . The value of $r$ squared is 0.433 . This means that the influence of the discipline variable on company performance is $43.3 \%$ and the rest is influenced by other variables that are not included in the equation model.

Motivation variables partially affect company performance. The $\mathrm{t}$ value is 27.146. The significance value is 0.00 . This significant value is smaller than 0.05 . The value of $r$ squared is 0.770 . This means that the influence of the motivation variable on company performance is $77.0 \%$ and the rest is influenced by other variables that are not included in the equation model.

Organizational citizenship behavior variables partially influence motivation. The $\mathrm{t}$ value is 15.021 . The significance value is 0.00 . The value of $r$ squared is 0.506 . This means that the influence of the motivation variable on company performance is $50.6 \%$ and the rest is influenced by other variables that are not included in the equation model.

The discipline variable partially affects motivation. The value of $r$ squared is 0.597 . This means that the influence of the discipline variable on motivation is $59.7 \%$ and the rest is influenced by other variables that are not included in the equation model.

The effect of organizational citizenship behavior on company performance is 0.600 . The influence of organizational citizenship behavior on performance through motivation is $0.712 \times 0.878=$ 0.625 . In this case, the indirect effect is greater than the direct effect, so it can be said that the motivation variable is intervening. The direct effect of organizational citizenship behavior on company performance is 0.657 . While the influence of work organizational citizenship behavior on company performance through motivation is $0.772 \times 0.878=$ 0.678 . In this case, the indirect effect is greater than the direct effect, so it can be said that the work motivation variable is intervening.

\section{Recommendations}

Organizational citizenship behavior needs to be improved to improve company performance. Organizational citizenship behaviors such as helping co-workers complete their work, thinking about company development outside of their working hours, and other behaviors are very useful in improving company performance. To increase this behavior, companies need to develop unselfish behavior towards employees, increasing concern for the organization and develop a sense of humanity in completing work. Another thing that needs to be considered in improving company performance is increasing employee discipline at work. Employees who have high discipline are expected to increase their productivity and company performance. This activity can be done through the application of a disciplined attitude when it comes to work, work and when you go home. A disciplined attitude also needs to be improved in terms of completion of work with timely completion. Motivation also needs to be increased by meeting employee needs, 
fulfilling employee desires after negotiating with the company and listening to employee complaints.

\section{REFERENCES}

1. Shrestha, T. (1997). Metodologi Ilmu Pemerintahan. Jakarta: Rineka Cipta.

2. Noe, R. A., Hollenbeck, J. R., Gerhart, B., \& Wright, P. M. (2017). Human resource management: Gaining a competitive advantage. New York, NY: McGraw-Hill Education.

3. Robbins, S. P. (2016). Organizational behavior.

4. Silalahi, B. (2004). Corporate Culture and Performance Appraisal. Jakarta: Al-Hambra, 200.

5. Dessler, G. (2008). Human Resources Management, $8^{\text {th }}$ Edition, Prentice Hall, International Inc.

6. Arikunto, S. (2010). Prosedur Penelitian. Jakarta: PT. Rineka Cipta.

7. Weiner, B. (1972). Theories of Motivation from Mechanism to Cognition. Chicago: Markham Publishing.

8. Uno, Hamzah, B. (2009). Teori motivasi dan Pengukurannya (Analisis di Bidang Pendidikan). Bumi Aksara. Jakarta.

9. Pritchard, M. P., Havitz, M. E., \& Howard, D. R. (1999). Analyzing the commitment-loyalty link in service contexts. Journal of the academy of marketing science, 27(3), 333.

10. Siagian, Sondang, P. (2008). Manajemen Sumber Daya Manusia. PT. Bumi Aksara. Jakarta.

11. Makmun, A.S. (2003). Psikologi Pendidikan. Bandung: Rosda Karya Remaja.

12. Elliot. (2000). Educational Psychology: Effective Teaching, Effective Learning, The Mc. Graw Hill Companies, America.

13. Podsakoff, P.M., Ahearne, M., \& McKenzie, S.B. (1997). Organizational Citizenship Behaviour and the Quantity and Quantity of Work Group Performance. Journal of Applied Psychology, Vol. 82: 262-270.

14. Siswanto, S. (2003). Manajemen Tenaga Kerja Indonesia, edisi 2, PT. Bumi Aksara, Jakarta.

15. Moeheriono. (2009). Pengukuran Kinerja Berbasis Kompetensi: Competency Based Human Resource Management. Jakarta: Ghalia Indonesia.

16. Mangkuprawira, S.T. (2011). Manajemen Sumber Daya Manusia Strategik, Ghalia Indonesia, Bogor

17. Wibowo. (2013). Manajemen Kinerja. Jakarta. Jakarta. Rajawali.

18. Rivai, V., \& Sagala, E. Jauvani. (2009). Manajemen Sumber Daya Manusia Untuk Perusahaan. Rajagrafindo Persada. Jakarta. 